\title{
Mortui vivos docent [The dead teach the living]
}

\author{
Uliana Pidvalna ${ }^{1} \quad$ Lesya Mateshuk-Vatseba ${ }^{1}$ \\ ${ }^{1}$ Department of Normal Anatomy, Danylo Halytsky Lviv National \\ Medical University, Lviv, Ukraine \\ J Morphol Sci 2019;36:291-294.
}

\begin{abstract}
Address for correspondence Uliana Pidvalna, MD, PhD, Department of Normal Anatomy, Danylo Halytsky Lviv National Medical University, 69 Pekarska Street, Lviv, Ukraine 79010

(e-mail: uljaska.p@gmail.com).
\end{abstract}

\begin{abstract}
Keywords

- history of morphological sciences

- anatomical museum

- Danylo Halytsky Lviv National Medical University

- Henryk Kadyi Medical museums are a record of the history of the medical thought processes. The Anatomical museum of the Department of Normal Anatomy located in the Danylo Halytsky Lviv National Medical University was founded in 1894 by Professor Henryk Kadyi (1851-1912). The museum includes a number of unique objects and displays $>2,000$ specimens. These medical artifacts include both normal anatomy and malformed artifacts. The museum is divided into three sections that are arranged according to the systems of the body and a method of preparing specimens. The vast array of preserved specimens represents comparative, developmental, gender, systemic, dynamic, plastic, and descriptive anatomy. Besides the Anatomical museum, the historical treasure is the Anatomical Theater, the oldest auditorium at the Danylo Halytsky Lviv National Medical University that preserved its authenticity. These educational places teach us not only about morphology, but also help us appreciate the beauty of the human body.
\end{abstract}

\section{Introduction}

Are Medical museums only a part of history? Are they becoming extinct due to uprising digital obsession? Is there a place for them in the near future?

As the Latin expression claims "Mortui vivos docent", which means "the dead teach the living." Taking a journey through the Medical museum is taking a journey through the realm of the dead, the traces of the past. This museum resembles a living book of someone's life. Perhaps a life full of success and failure, honor and fear, love and injustice. But regardless of the destiny, those lives became an honorable teaching resource for everyone. Although Anatomical Museums continue their longstanding role as an educational resource for clinicians, like other medical museums, they are enjoying a renaissance by opening its doors to the wider community. ${ }^{1}$

Anatomical museums seemed to appear first in the $16^{\text {th }}$ and $17^{\text {th }}$ centuries and were the part of natural history museums. ${ }^{2}$ Every medical faculty tried to establish a lecture room, a library, laboratories, and training rooms, where dissections could take place. The most impressive and important preparations of anatomical specimens were consequently taken to the museums.

received

August 5, 2019

accepted

August 14, 2019
DOI https://doi.org/

10.1055/s-0039-1698377. ISSN 2177-0298.

\section{Anatomical Museum, Department of Normal Anatomy, Danylo Halytsky Lviv National Medical University}

\section{History}

The building of fundamental sciences founded by Prof. Kadyi in 1894 was constructed on the modern scientific principles. It was built following the project of the architect Jozef Braunseis (1837-1914) with the collaboration of Prof. Henryk Kadyi and of the architect Ivan Levynskyi (1851-1919). ${ }^{3-5}$

Prof. Henryk Kadyi (1851-1912) began his educational journey at the Lviv gymnasium (Lviv, Ukraine) (-Fig. 1). After that, he joined the Jagiellonial University (Krakow, Poland) and was admitted at the Medical University of Vienna (Vienna, Austria), where in 1875 he received the degree of Doctor of Medicine. In 1878, he returned to Krakow as an Associate Professor at the Department of Comparative Anatomy and, in 1881, moved to Lviv as head of the Department of Normal Anatomy and Histology. 6,7

Together with his colleagues, Professor Kadyi organized the scientific work of the Department of Anatomy. He was

Copyright $\odot 2019$ by Thieme Revinter Publicações Ltda, Rio de Janeiro, Brazil 


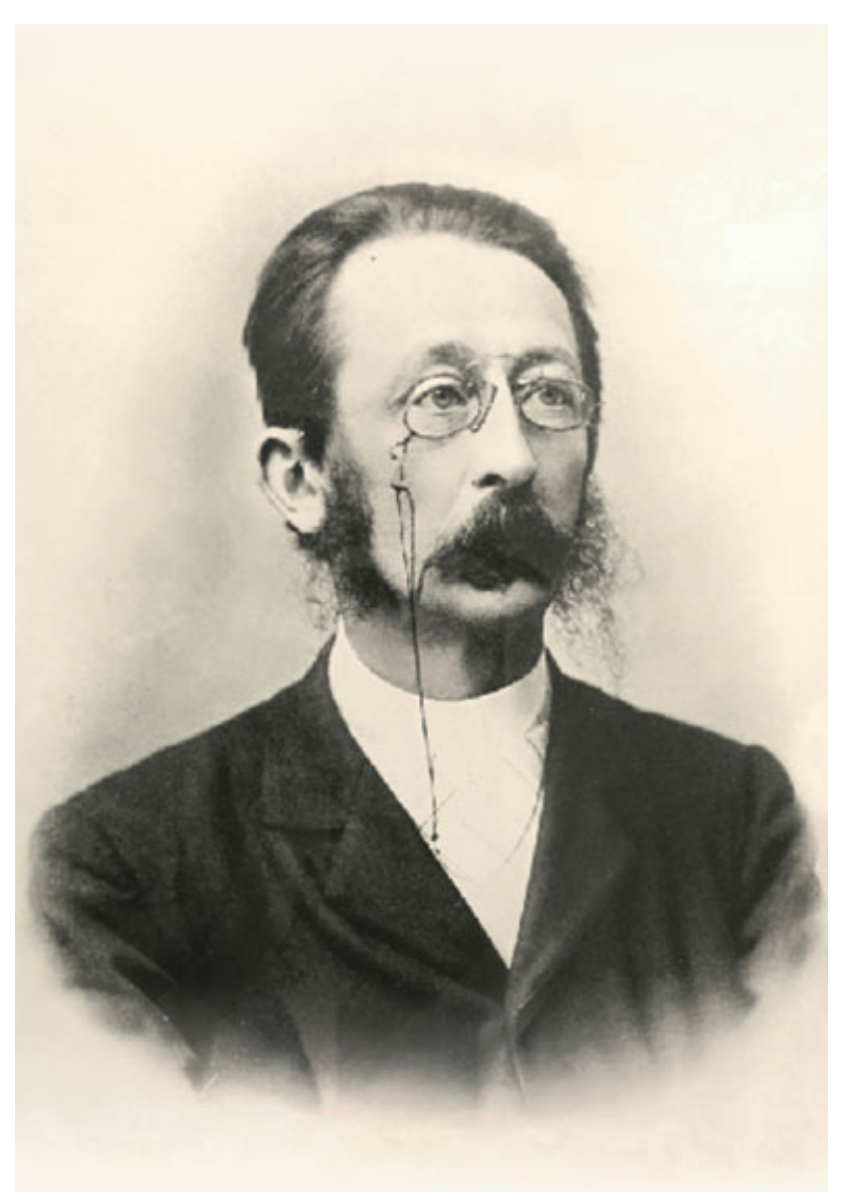

Fig. 1 Professor Henryk Kadyi (1851-1912).

considered an innovator and an unsurpassed master of making anatomical preparations. He probably gained his fundamental knowledge from his mentor - Prof. Ludwik Karol Teichmann (1823-1895), the great Polish and world anatomist. He pioneered in the development of the method of manufacturing corrosion preparations using cellulose and paraffin. For painting nerve cells, heavy metal salts were used. Prof. Kadyi also introduced to use formalin in the preservation of cadavers in Lviv. ${ }^{6}$

In 1907, Prof. Henryk Kadyi was one of the organizers of the $10^{\text {th }}$ Congress of Medical Doctors and Polish Natural Sciences. Prof. Kadyi presented a method of staining of the gray matter of the brain and of the carmine core after treatment with uranyl acetate, in the Polish Archives of Biological and Medical Sciences (Polskie Archiwum Nauk Biologicznych i Lekarskich), which he both edited and published with his extensive involvement from 1901 to 1907. ${ }^{6,7}$

Prof. Henryk Kadyi passed away suddenly and tragically from sepsis infection during the embalming of Count Stanisław Badeni, Marshall of the Galician Country Parliament on October 25, 1912..$^{5,7,8} \mathrm{He}$ was buried in the Lychakiv Cemetery - a necropolis of the intellectual elite of the city, which is located near the Medical University.

\section{The Museum Nowadays}

The Anatomical Museum of the Department of Normal Anatomy of the Danylo Halytsky Lviv National Medical University (Lviv, Ukraine) houses a comprehensive collection of $>2,000$ preparations. Those medical artifacts include both normal anatomy and malformed specimens. The museum has an extensive collection of articulated skeletons, individual fetal, adult and juvenile bones, as well as the skeletons and visceral bones of many animals. The particularly interesting artifacts are casts, corrosive, mummified organs of the cardiovascular and nervous system.

The museum is divided into three sections, each with their own focus point. Our Anatomical Museum is a dynamic place, as its materials are being used in practical classes for our medical students. They study systemic and descriptive anatomy; however, normal anatomy is a broader and deeper science. Artists and painters are also common visitors of the Museum as it displays sculptures of the human body and reconstructions of paintings by Leonardo da Vinci and Andreas Vesalius. Thus, using these artworks, dynamic and plastic anatomy is captured and learned in the Museum.

\section{The First Museum Section}

This section focuses on the form and function of the skeletal system and has numerous educational displays. They include locomotor system specimens such as muscles, joints and bones. Mostly, the first museum section is devoted to osteology. This collection includes skeletal material of different genders and ages, and also a fetal skeleton. Decalcified and cleared bones specimens reveal the paranasal sinuses in the skull and the trabecular pattern in the long bones.

The unique artifact is the skull with developing teeth (moving from primary to permanent) (-Fig. 2). Moreover, the museum showcases the sheer diversity of bone anomalies and congenital malformations (diversity of congenital cardiac defects and skeletal deformities), such as metopic (frontal) suture, suture bones, acrocephaly (tower skull); vertebral anomalies: assimilation of the atlas, and bone concrescence. Included in this section are the skeletons

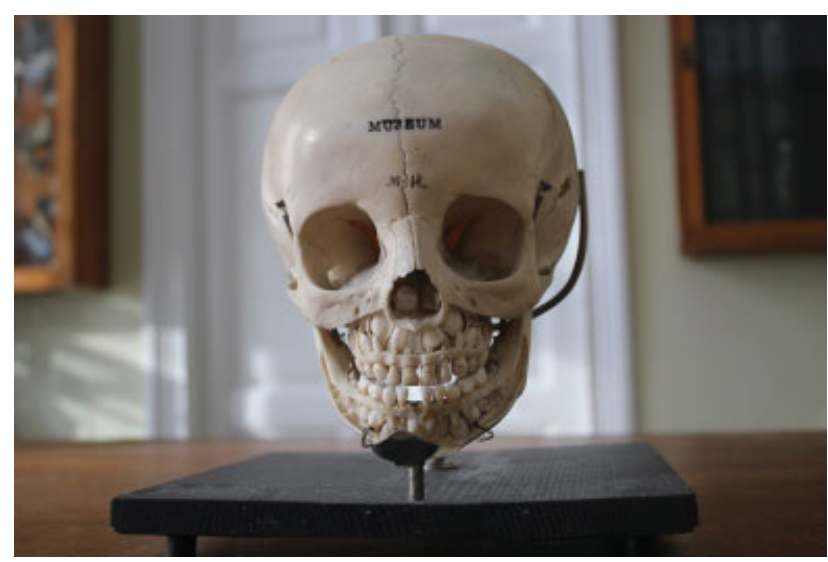

Fig. 2 The skull with developing teeth (moving from primary to permanent). 
with hypersthenic and asthenic body habitus that can be used to learn gender and constitutional anatomy. Moreover, a great collection of mammal skeletons can change your understanding of comparative anatomy.

\section{The Second Museum Section}

The collection in the second section comprises wet preparations of human tissues and organs and is divided according to the body systems: the urinary system; the respiratory system; the cardiovascular system; the digestive system; the nervous system; the endocrine system; the reproductive system; skin and soft tissues; and the sense organs. The collection contains exhibits of transverse, sagittal and frontal sections of the adult head, neck and trunk.

The collections in this section include a wide variety of deformities and defects. For example, in the urinary system collection you can observe ureteral duplication, a duplicated collecting system, horseshoe and pelvic kidneys, etc.

The nervous system collection includes $\sim 100$ brain sections in the sagittal, transverse and coronal parts that show the macroscopic details of cortical and basal gray matter and the white matter fiber tracts.

The most iconic collection in this section contains the

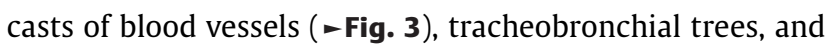
nerves. The most well-known, and perhaps the most curious

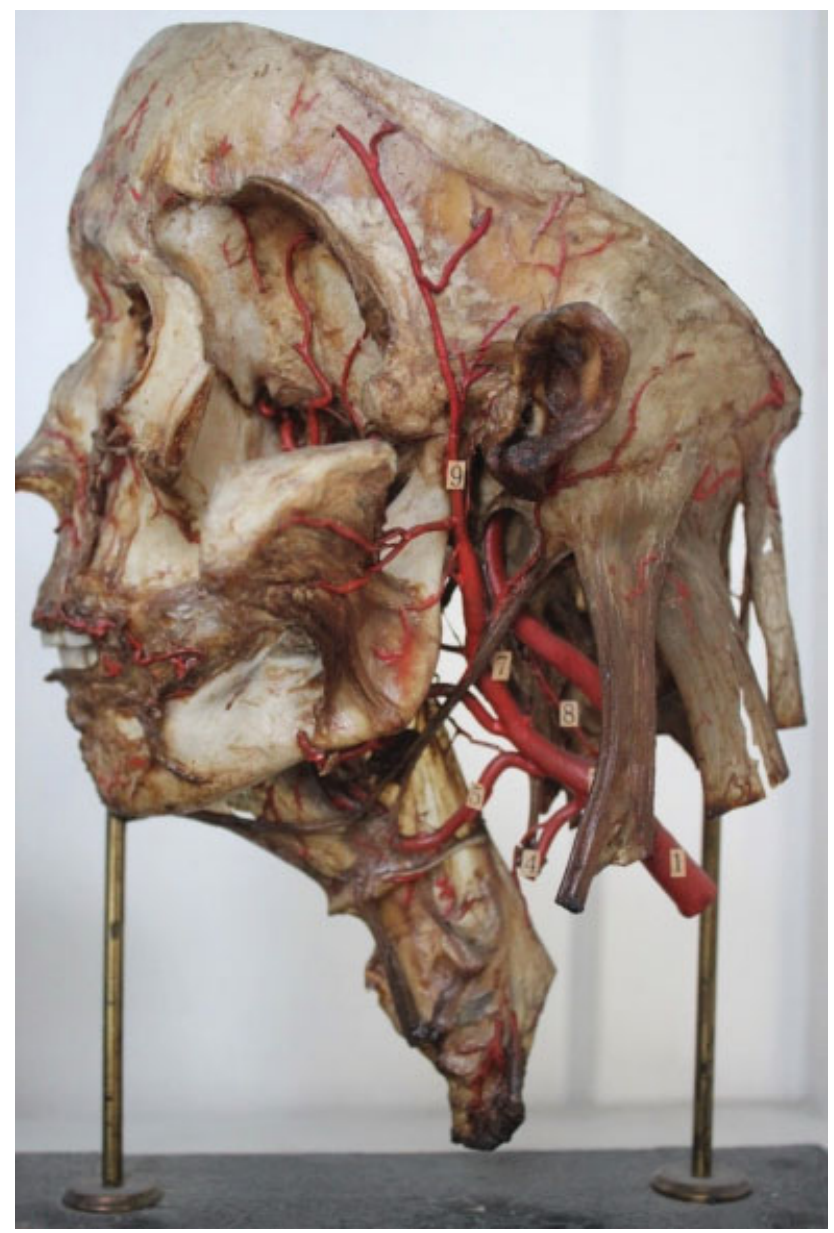

Fig. 3 Branches of the external carotid artery. items in the collection are vessels and nerves of the thoracic cavity, of the abdominal cavity, and of the upper and lower limbs.

\section{The Third Museum Section}

The specimens in the third section are displayed in the authentic cabinets that date back $\sim 120$ years (the period of the Austro-Hungarian Monarchy) (-Fig. 4). The weight of each cabinet is $\sim 500 \mathrm{~kg}$ (or $1102 \mathrm{lbs}$ ). They have a very interesting feature - it is impossible to open or close them without special position of the cabinet legs.

This section includes specimens depicting the comparative anatomy of viscera of humans and mammals; the most common are the exhibits of hearts and lungs. Visitors can observe a range of heart preparations that belonged to different mammals, such as echidna, stork, lion, bear, and horse.

Moreover, this section displays the exhibits of the casts of blood vessels. A mummified preparation of the aorta and its branches, the arterial and venous network (hand and foot); variations in branching of the aortic arch, of the thyrolinguofacial trunk, and the transposition of central vessels are of particular relevance in the context of surgery. The exceptional specimens are the casts of the entire vascular system of stillborn babies.

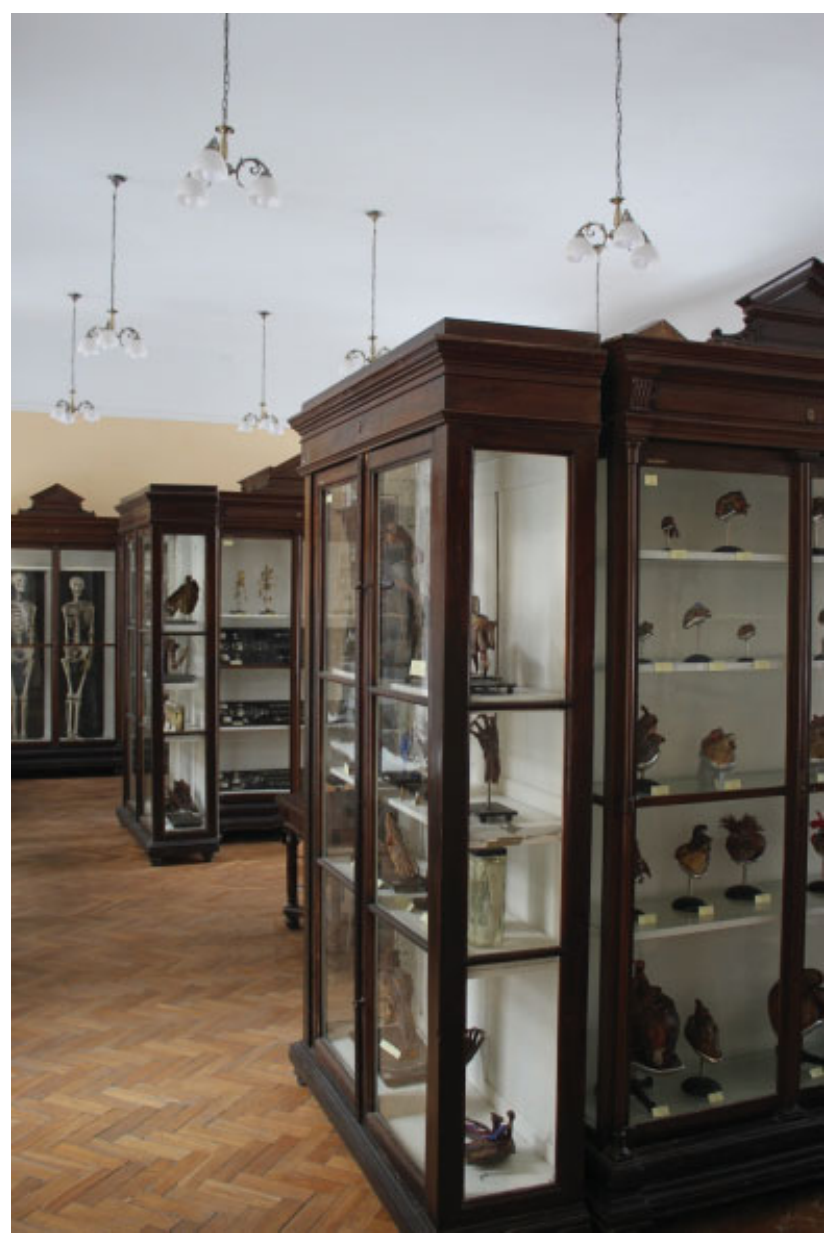

Fig. 4 Authentic cabinets in the third museum hall. 


\section{Anatomical Theater}

The oldest auditorium at the Danylo Halytsky Lviv National Medical University is the Anatomical Theater. The Lecture hall can seat 200 people. During lectures, conducted by Prof. Henryk Kadyi, 200 students and professors observed the dissection of human cadavers. Prof. Adolf Beck and Prof. Vladyslav Shymonovych also presented their lectures here. The Anatomical Theater in Lviv preserved its authenticity and is a place that helps us understand our relationship with the tangible and intangible heritage of humanity.

\section{Conclusions}

According to the founder of modern human anatomy, Andreas Vesalius, "Anatomia fundamentum medicinae est." This statement remains relevant today. Human Anatomy is the first medical discipline a student begins to study after enrolling in a medical university. ${ }^{9}$ Thus, anatomical museums must continue to be accessible to the public. Anatomical museums teach us not only about morphology but also help us appreciate the beauty of the human body. These museums preserve knowledge that has been hard-won by scientists and are a record of the history of the medical thought processes.

The great collection of the Department of Normal Anatomy of the Danylo Halytskyy Lviv National Medical University includes both normal anatomy and malformed artifacts. The Museum is a place of great interest for a wide audience within the medical community, as well as many physicians and surgeons. Practitioners who span the clinical disciplines and biomedical sciences, such as anatomists and pathologists, also profit greatly by visiting anatomical museums.

Conflicts of Interests

There are no conflicts of interest to declare.

Acknowledgments

We are indebted to those who donated their bodies to science.

\section{References}

1 Connor J. Medical museums. CMAJ: Canadian Med Assoc J 2014; 186(03):215

2 Turk JL. The medical museum and its relevance to modern medicine. JR Soc Med 1994;87(01):40-42

3 Noha O. Levinsky Ivan - architect, entrepreneur, philanthropist. Lviv: Center for Europe; 2009:192

4 Kvyatkovsky AR. Town Hall. Lychakiv Cemetery [Tsvyntar na Lichakovi]. Lviv: Pyramid Literary Agency; 2001:198

5 Krypiakevich I. Historical Passages in Lviv [Istorychnyi passazh]. Lviv: Kamenyar; 2001:167

6 Wincewicz A, Turek-Pietrzykowska M. Scientific and organizational achievements of Professor of Anatomy Henryk Kadyi - Rector Vigilantissimus Universitatis Leopoliensis. Rom J Morphol Embryol 2017;58(04):1623-1629

7 Masna Z, Mateshuk-Vatseba L, Kryvko Y. Lviv Anatomical School. History pages. [Lvivska anatomichna shkola. Storinky istoriyi]. Lviv: University Publishing House; 2017:70

8 Krysa L, Figol R. Lychakiv Necropolis [Lychakivs'kyy nekropol]. GuidebookLviv2006:480

9 Pidvalna U, Mateshuk-Vatseba L. Anatomical museum of Danylo Halytsky Lviv National Medical University - a tool for interactive learning. Proc Shevchenko Sci Soc. Med Sci 2018;52(01):33-38 